\title{
STUDI POLA ASUH ORANG TUA PADA ERA MODERN DI KOTA TARAKAN
}

\author{
Siti Fatimah, Urotul Aliyah \\ Fakultas Keguruan dan Ilmu Pendidikan, Universitas Borneo Tarakan \\ syifasitifatimah1@gmail.com
}

\begin{abstract}
The purpose of this research to find out how parents do parenting in the modern era of tarakan city. The method of the research used in the study is a qualitative method by using design case study. The subject in this study consists of three parents in the modern era. As of the subject matter of the research process was snowball sampling. The method of data collection was observation and interviews.

The result showed that (1) Cendana's family is incline to the democratic parenting, it can be showed when the child asks something, the parents are, consider first the good and back side, the parents pay attention about the hearty, the education, and the child's religion problem (2) Cemara's family is incline to the authoritative parenting, it can be showed to each parents' wishes should be do, the child is afraid and the effect rare to cry. Meanwhile the parents still pay attention the health of child. But to the education and religion, the parents incline neglectful parenting. The parents feel when the child in institute, the child is not beeded the guidance at home. The parents feel when they give the complee facilities, the duty of the parents are done (3) cempaka's family is incline to the authoritative parenting, it can be shower when the child make a mistake, the parents divectly give the punishument. Neanwhile the parents still the child's health, but in education and religion the parents is incline to negiectful parenting. The parents think handover to institute intentional becaous the parents do not have so much time for the child and the parents give the complete facilities for making happy their child.
\end{abstract}

Keywords: Parenting, Parents, Modern Era.

\section{PENDAHULUAN}

Tarakan merupakan kota terbesar di Provinsi Kalimantan Utara (Kaltara). Kota ini terpisah dari daratan Kalimantan dan berada pada sebuah pulau kecil. Luas Kota Tarakan adalah $250,80 \mathrm{~km}^{2}$ dengan populasi penduduk yang mencapai 239.787 jiwa. Kota ini memiliki semboyan yang dikenal dengan istilah "BAIS" (Bersih, Aman, Indah, dan Sejahtera).

Secara resmi Kota Tarakan berdiri pada tanggal 15 Desember 1997. Pada saat itu Kota Tarakan masih menjadi bagian dari Provinsi Kalimantan Timur (Kaltim). Sejak tahun 2002, Kota Tarakan menjadi bagian dari Provinsi Kalimantan Utara seiring dengan pemekaran provinsi tersebut dari Provinsi Kalimantan Timur. Berdirinya Kota Tarakan

ditetapkan berdasarkan Undang-Undang RI No. 29 Tahun 1997. Sebelumnya Kota
Tarakan hanya berupa kota administratif yang masuk dalam wilayah Kabupaten Bulungan.

Suku asli Kota Tarakan adalah suku Tidung, namun dalam perkembangannya dihuni pula oleh sukusuku lain, yaitu suku Dayak, suku Banjar, suku Jawa, suku Bugis, suku Batak, suku Toraja, keturunan Tionghoa, dan lain-lain. Dahulu, wilayah Kota Tarakan dipimpin oleh pemerintah Kerajaan Tidung atau disebut juga Kerajaan Tarakan yang memerintah suku Tidung (Purba, 2008).

Kota Tarakan terdapat berbagai macam pekerjaan yang menuntut orang tua untuk lebih berfokus pada pekerjaan daripada memperhatikan pertumbuhan dan perkembangan anak. Misalnya orang tua yang bekerja sebagai tenaga pendidik yang bekerja dalam kurun waktu 7-8 jam perhari. Kesibukan bekerja di sekolah menuntut orang tua untuk fokus pada pekerjaan 
sehingga harus meninggalkan anak di rumah, meskipun orang tua sering kali terpaksa membawa anak ketika bekerja. Oleh sebab itu orang tua memilih memberikan teknologi pada anak seperti handphone agar anak mampu berkembang mengikuti perkembangan zaman dan tidak menganggu pekerjaan orang tua, sehingga orang tuapun lebih fokus dan tenang dalam bekerja mencari nafkah.

Seiring perkembangan zaman di Kota Tarakan, teknologi yang digunakanpun juga semakin berkembang. Hal ini juga mempengaruhi perkembangan kepribadian individu, oleh sebab itu peran keluarga sangat berpengaruh dalam mengawasi penggunaan teknologi pada anak.

Keluarga merupakan Lembaga pertama dalam kehidupan anak, tempat ia belajar menyatakan diri sebagai makhluk sosial. Dalam keluarga umumnya anak ada hubungan interaksi yang intim dengan orang tuanya. Keluarga memberikan dasar pembentukan tingkah laku, watak, moral dan pendidikan anak (Kartini kartono, 1992).

Keluarga merupakan suatu kelompok sosial yang bersifat langgeng berdasarkan hubungan pernikahan dan hubungan darah. Keluarga adalah tempat pertama bagi anak, lingkungan pertama yang memberi penampungan baginya, tempat anak akan memperoleh rasa aman (Gunarsa, 2002).

Keluarga masa kini berbeda dengan keluarga masa dulu. Dalam kaitan keluarga, orang-orang mengalami pergolakan dan perubahan yang hebat, khususnya mereka yang hidup di kota. Karena itu, gambaran mengenai ikatan fungsi keluarga jauh berbeda jika dibandingkan dengan keluarga yang berada di tengah segala kemewahan materi.

Keluarga masa dulu, yaitu keluarga yang belum terkena pengaruh penggantian tenaga manusia dengan tenaga mesin, merupakan keluarga yang banyak fungsinya dan ikatan kekeluarga yang kuat. Masingmasing anggota keluarga mempunyai peranan yang penting dalam roda kehidupan serta saling membutuhkan. Sebaliknya, keluarga masa kini sudah banyak kehilangan fungsi dan arti. Fungsi pendidikan sudah diserahkan pada lembaga-lembaga pendidikan seperti sekolah, sehingga tugas orang tua dalam perkembangkan segi intelektual anak menjadi jauh lebih ringan. Peralatan yang serba modern dan mekanis, mengganti tenaga manusia dengan tenaga mesin dan listrik, mengakibatkan tenaga manusia tidak lagi dibutuhkan. Misalnya, untuk memperoleh pakaian baru tidak perlu menunggu ibu menemaninya, melainkan cukup membeli pakaian jadi (Gunarsa, 2012). Oleh sebab itu, pola asuh orang tua sangat dibutuhkan dalam mencapai tugas pertumbuhan dan perkembangan anak khusunya di Kota Tarakan.

Pola asuh orang tua adalah suatu cara yang dapat ditempuh orang tua dalam mendidik anak sebagai perwujudan dari rasa tanggung jawab kepada anak. Peran keluarga menjadi penting untuk mendidik anak baik dalam sudut tinjauan agama, tinjauan sosial kemasyarakatan maupun tinjauan individu. Jika pendidikan keluarga dapat berlangsung dengan baik maka dapat menumbuhkan perkembangan kepribadian anak menjadi manusia dewasa yang memiliki sikap positif (Papalia, 2008). Cara mendidik dan kebiasaan yang dilakukan oleh orang tua terhadap anak di Kota Tarakan tidak jauh berbeda dengan kota lainnya, terutama dalam penggunakan teknologi, seperti memberikan handphone pada anak agar tidak menagis, marah, dan mengganggu orang.

Seiring dengan perkembangan zaman, pengasuhan orang tua dituntun harus lebih ekstra. Kemajuan teknologi saat ini sangat pesat, berbagai kemajuan teknologi dapat kita peroleh dengan mudahnya. Melihat perkembangan teknologi sekarang ini, penggunaan perangkat digital bagi kehidupan anak telah berpengaruh terhadap kehidupan anak (Winarno, 2012). Seiring dengan perkembangan zaman dan kemajuan perkembangan komunikasi antar manusia dapat dilakukan dengan berbagai alat dan sarana. Salah satunya adalah alat komunikasi yang banyak digunakan saat ini diantaranya internet, handphone, facebook, twitter, dan lain-lain. Sehingga pengawasan penggunaan teknologi sangat penting, karena banyak informasi yang tidak sesuai dengan tahap perkembangannya. Oleh sebab itu, penggunaan teknologi harus dicermati dengan baik oleh orang tua agar dapat 
mengetahui kemampuan anak dalam menggunakan perangkat digital.

Anak merupakan individu yang unik, dimana mereka mempunyai kebutuhan yang berbeda-beda sesuai dengan tahap usianya (cahayaningsih, 2011). Anak adalah harapan orang tua, harapan masa depan keluarga bahkan bangsa. Oleh sebab itu perlu dipersiapkan agar kelak menjadi manusia yang berkualitas, sehat, bermoral dan berguna bagi dirinya, keluarga, agama dan bangsanya. Anak seharusnya perlu dipersiapkan sejak dini agar mereka mendapatkan pola asuh yang benar saat mengalami proses pertumbuhan dan perkembangan.

Berdasarkan permasalahan di atas, penulis melakukan observasi awal yang dilakukan penelitian pada tanggal 16 April 2018 di kompleks perumahan gunung lingkas, yang merupakan salah satu kelurahan yang ada di Tarakan, diperoleh informasi bahwa dalam mendidik anak pendekatannya berbeda berdasarkan tingkat usia dari anak, karena anak yang sudah remaja tingkat berfikirnya berbeda sehingga dalam mendidiknya juga harus berbeda. Berkaitan dengan era modern seperti saat ini, dimana semua lebih cenderung ke teknologi, dalam hal ini lebih dipertegas lagi dengan wawancara yang dilakukan diperoleh informasi bahwa dalam menanggapi perkembangan teknologi, anak diberikan waktu yang lebih banyak dalam menggunakan handphone.

Diketahui dari hasil wawancara yang penulis lakukan bahwa permasalahan yang terdapat dalam pengasuhan anak diantaranya yaitu orang tua yang sibuk bekerja diluar rumah seperti menjadi tenaga pendidik yang hampir setiap hari menghabiskan waktu diluar rumah sehingga komunikasi dengan anak berkurang, kurangnya peran ayah dalam mendidik anak, dan kurangnya pengawasan orang tua dalam penggunaan handphone, sehingga anak lebih mudah terpegaruh oleh lingkungan luar.

Penelitian ini lebih dipertegas dengan penelitian sebelumnya oleh Nasrun Faisal "Pola Asuh Orang Tua Dalam Mendidik Anak Di Era Digital". Hasil dalam penelitian tersebut yaitu mendidik anak di era digital dengan cara menerapkan pola asuh yang tidak otoriter karena anak tidak senang dipaksa melainkan dibujuk dan cenderung dibiarkan namun juga harus tetap diawasi oleh orang tua. Selain itu orang tua juga harus mampu memahami ragam aplikasi yang mendidik anak dan memandu anak untuk memainkannya dengan baik serta mengawasi penggunaan media informasi tersebut agar tidak menyimpang dari nilainilai pendidikan islam.

Berdasarkan latar belakang masalah yang dipaparkan, maka peneliti tertarik untuk melakukan penelitian mengenai "Studi Pola Asuh orang tua pada era Modern di Kota Tarakan".

\section{METODE PENELITIAN}

Metode penelitian ini, menggunakan metode kualitatif dengan desain studi kasus. Menurut Patton (dalam Ahmadi, 2014), Metode kualitatif adalah untuk memahami fenomena yang sedang terjadi secara alamiah (natural) dalam keadaan-keadaan yang sedang terjadi secara alamiah. Penelitian ini dilakukan terhadap Orang tua pada era modern di Kota Tarakan khususnya di Kecamatan Tarakan Timur.

\section{SUBJEK PENELITIAN}

Adapun untuk keperluan penelitian ini yang menjadi Subjek adalah tiga keluarga dan menggunakan teknik snowball sampling sebagai teknik pengambilan sampel yang sering digunakan dalam penelitian kualitatif.

\section{TEKNIK PENGUMPULAN DATA}

Teknik pengumpulan data yang digunakan dalam penelitian ini adalah Observasi dan wawancara. Teknik analisis data mengacuh pada konsep model Miles dan Huberman yaitu interactive model.

\section{HASIL DAN PEMBAHASAN}

Hasil penelitian menunjukkan bahwa pada keluarga cendana selalu memperhatikan makanan yang dikonsumsi oleh anak, selalu membimbing dan mengajari anak ketika belajar, mengenalkan dan mengajari anak padapada agama sejak usia dini, menitipkan anak pada keluarga, mempertimbangkan terlebih dahulu sebelum memberikan sesuatu, anak terbiasa bertemu dengan orang lain kerena sejak dini tidak diasuh seutuhnya oleh orang tua,dan tidak ada liburan khusus keluarga. Pada keluarga 
cemara selalu memperhatikan asupan gizi yang seimbang pada anak, mempercayai pendidikan pada lembaga, mengenalkan agama sejak usia dini akan tetapi diserahkan kepada lembaga keagamaan, memberikan fasilitas WiFi didalam rumah, memberikan segala sesuatu kepada anak jika anak memintanya dengan baik, membiasakan anak beradaptasi dengan lingkungan dan selalu ada waktu liburan keluarga. Pada keluarga cempaka selalu membiasakan pola hidup sehat, mempercayai pendidikan pada lembaga, menyerahkan kepda lembaga sejak usia dini, memberikan Handphone pada anak, memberikan segala sesuatu yang diminta oleh anak, membiasakan anak pada lingkungan yang ramai dan pada saat liburan dimanfaatkan bersama keluarga.

Berdasarkan teori dan

hasil penelitian, dapat dilihat bahwa pola asuh orang tua pada era modern di kota Tarakan khususnya di Kecamatan Tarakan Timur terdapat tiga pola asuh yaitu pola asuh otorier, poa asuh demokrasi, dan pola asuh abai (tidak peduli).

\section{KESIMPULAN}

Berdasarkan hasil penelitian menunjukkan bahwa Keluarga Cendana cenderung mengarah pada pola asuh demokrasi, hal ini ditunjukan ketika anak meminta sesuatu orang tua mempertimbangkan terlebih dahulu baik buruknya, orang tua memperhatikan tentang kesehatan, pendidikan dan masalah keagamaan anak. Keluarga Cemara cenderung mengarah pada pola asuh otoriter, hal ini ditunjukan pada setiap keinginan dari orang tua harus dilakukan, anak merasa takut sehingga anak jarang menangis. akan tetapi orang tua tetap memperhatikan kesehatan anak. Namun pada pendidikan dan keagamaan orang tua cenderung mengarah pada pola asuh abai (tidak peduli) orang tua merasa ketika anak dimasukkan ke lembaga sudah tidak perlu lagi dibimbing ketika dirumah dan orang tua merasa ketika memberikan fasilitas yang lengkap maka tugas sebagai orang tua akan selesai. Keluarga Cempaka cenderung mengarah pada pola asuh otoriter, hal ini ditunjukkan ketika anak melakukan kesalahan orang tua langsung menghukum anak. Akan tetapi orang tua tetap memperhatikan kesehatan anak. Namun pada pendidikan dan keagamaan orang tua cenderung mengarah pada pola asuh abai (tidak peduli) orang tua beranggapan bahwa sengaja menyerahkan pada lembaga karena merasa tidak memiliki waktu yang banyak untuk anak dan orang tua memberikan fasilitas yang lengkap pada anak agar anak merasa senang.

\section{DAFTAR PUSTAKA}

Adawiah Rabiatul. 2017. Pola asuh orang implikasinya terhadap pendidikan anak (studi pada masyarakat Dayak di kecamatan Halong Kabupaten Balangan). Jurnal Pendidikan Kewarganegaraan, 7(1)

Ahmadi, Rulam. 2014. Metodologi

Penelitian Kualitatif. Jakarta: Arruzz Media

Alia, Tesa. 2018. Pendampingan Orang Tua Pada Anak Usia Dini dalam Penggunaan Teknologi Digital. A Journal of Language, Literature, Culture, and Education, $14(1)$

Cahayaningsih Dwi Sulastyo. 2011. Pertumbuhan Perkembangan Anak \& Remaja. Jakarta: CV. Trans Info Media

Depdikbud. 1988. Kamus Besar Bahasa Indonesia. Jakarta: Balai Pustaka

Elizabeth B. Hurlock. 2000. Perkembangan Anak. Jakarta: Erlangga

Faud Ihsan. 2005. Dasar-dasar Pendidikan. Jakarta: PT Rineka

Fitria, Nita. 2016. Pola Asuh Orang Tua Dalam Mendidik Anak Usia Presekolah Ditinjau dari Aspek Budaya. Jurnal Fokus Konseling, 2(2)

Gunarsa, DR Singgah D. 2002. Psikologi Perkembangan. Jakarta: PT BPK Gunung Mulia

Gunarsa Yulia D, Singgah D. Gunarsa. 2012. Psikologi untuk keluarga. Jakarta: PT BPK Gunung Mulia

Gunawan imam. 2013. Metode Penelitian Kualitatif. Jakarta: PT Bumi Aksara

Herimanto dan Winarno. 2012. Ilmu Sosial \& Budaya Dasar. Jakarta: PT Bumi Aksara

Kartini, Kartono. 1992. Pengantar Ilmu Menddik Teoritis (apakah 
pendidikan masih diperlukan).

Jakarta: CV. Mandiri Maju

Koesoema A Dodi. 2007. Pendidikan Karakter Strategi Mendidik Anak dizaman global. Jakarta: PT Grasindo

Kusumastuti, diah Andriandi Dkk. 2017. Perilaku mengakses situs porno pada remaja berdasarkan pola asuh orang tua. Indonesia jurnal kesehatan, 1(1)

Muallifa. 2009. Psycho Islamic Smart Parenting. Jogjakarta: Diva Press

Moleog, Lexy J. 2014. Metodologi Penelitian Kualitatif. Bandung: PT Remaja Rosdakarya

Noe'man, Rani Razak. 2013. Amazing Parenting. Jakarta Selatan: PT Mizan Publika

Papalia, Danie E. 2008. Human Development : Psikologi Perkembangan. Jakarta: Kencana Prenada Media Group

Purba, Juniar. 2008. Sejarah Kota Tarakan. Pontianak: Balai Pelestarian Sejah dan Nilai Tradisional Pontianak.

Sugiyono. 2015. Metode Penelitian Pendidikan. Bandung: Alfabeta

Sukiman. 2016. Seri Pendidikan Orang Tua Mendidik Anak Di Era Digital. Jakarta: Kementerian Pendidikan dan Kebudayan

Tridhonanto Al. 2014. Mengembangkan Pola Asuh Demokrasi. Jakarta: PT Elex Media Komputindo

Wijanarko, Jarot Dkk. 2016. Intim Orangtua-Anak smart Parnting Di Era Digital. Jakarta: Keluarga Indonesia Bahagia

Wulansari, Nyi Mas Diane. 2017. Didiklah Anak Sesuai Zamannya, Jakarta Selatan: PT Visimedia Pustaka 